Board of Governors of the Federal Reserve System

International Finance Discussion Papers

Number 742

November 2002

Productivity, Investment, and Current Accounts: Reassessing the Evidence

Jaime Marquez

NOTE: International Finance Discussion Papers are preliminary materials circulated to stimulate discussion and critical comment. References in publications to International Finance Discussion Papers (other than an acknowledgment that the writer has had access to unpublished material) should be cleared with the author or authors. Recent IFDPs are available on the Web at www.federalreserve.gov/pubs/ifdp/. 


\title{
Productivity, Investment, and Current Accounts: Reassessing the Evidence
}

\author{
Jaime Marquez*
}

\begin{abstract}
The most widely accepted explanation for the inverse association between private investments and current accounts [Glick and Rogoff, 1995] rests on data for manufactures through 1990. Is this consensus robust to revisions to the national accounts and the expansion of information technologies since 1990? To address this question I replicate their results and I find that post 1990 developments eliminate the support for such a conclusion. I also implement alternative formulations and find, again, a lack of empirical support for their findings. Thus I examine the role of measurement errors and focus on the treatment of the manufacturing sector as representative of the whole economy and the exclusion of the contribution of capital when measuring productivity. Correcting these two measurement errors restores to Glick and Rogoff's conclusion its original strength.
\end{abstract}

JEL Classification: O4, F4, E2, C3, C5

Keywords: Productivity, G-7 countries, current account, private investment, FIML, endogenous growth.

${ }^{*}$ Staff economist of the Division of International Finance of the Federal Reserve Board. I am very grateful to Reuven Glick and Talan İscan for detailed comments; to Neil Ericsson, Jon Faust, Joe Gruber, Dale Henderson, and John Rogers for suggestions; to Wolodar Lysko and Mike Harper, from the BLS, for providing data and answering questions about BLS data. Also, I am grateful to Reuven Glick for providing the data from Glick and Rogoff (1995); to Shing-Yi Wang for replicating the results of that paper; to Lisa Workman for helping with the productivity data from the OECD; and to participants in presentations at the Federal Reserve Board, at the 2001 Midwest Meetings of the International Economics group (University of Wisconsin at Madison and Penn State University), at the 2002 Summer Meetings of the Econometric Society (UCLA); and at the System Committee of International Economic Analysis. The results are based on PcGive10 and Stata. The views in this paper are solely the responsibility of the author and should not be interpreted as reflecting the views of the Board of Governors of the Federal Reserve System or of any other person associated with the Federal Reserve System. 


\section{Introduction}

The most widely accepted explanation of the inverse correlation between movements in private investments and current accounts rests on the work of Glick and Rogoff (1995). They report (page 186) that

Investment consistently responds positively and significantly to both country specific shocks and global productivity shocks. The current account responds negatively and generally significantly to countryspecific shocks; as the model predicts, there is little or no response to global shocks.

This finding rests, however, on productivity data from the manufacturing sector through 1990 and the question is whether it is robust to developments since then.

Two developments could undermine the applicability of their findings to recent observations. First, the substantial expansion of the information technology (IT) sector, by globalizing the production of manufactures, could erode the distinction between country-specific and global productivity shocks which is central to their conclusion. Second, investment in the national accounts has been re-defined to include firms' spending on computers and software; the data used by Glick and Rogoff pre-date such a redefinition. This change is important for several countries because the substantial declines in the prices of computers and software have induced a sharp increase in these two components and thus in private investment. Overall, then, whether their conclusion is immune to these developments is not obvious and settling this question is what I do here.

To that end, I start in section 2 by replicating their results and then examining whether they hold after allowing for data revisions and for developments outside their sample. I find that the conclusions reached by Glick and Rogoff do not hold once one allows for these considerations. In other words, if they were to implement today their empirical strategy, their results would not support the above quotation.

Several factors may explain this lack of corroboration and section 3 examines the separate roles of data revisions and post-1990 developments. I find that revisions in the national-income accounts are not responsible for the breakdown of their conclusion but that developments since 1990 are to blame. This finding raises the question of whether the profession's understanding of 
the role of productivity shocks in explaining the inverse correlation between private investment and current accounts remains valid.

To address this question I implement alternative formulations and find, again, a lack of empirical support for the findings of Glick and Rogoff. Thus I examine the role of measurement errors and focus on two possibilities: the treatment of the manufacturing sector as representative of the whole economy and the exclusion of the contribution of capital when measuring productivity. Correcting these two measurement errors restores to Glick and Rogoff's conclusion its original strength.

\section{Reassessment of Linkages}

\subsection{Empirical Formulation}

Glick and Rogoff explain changes in the current account and private investment with a model where both consumers and firms optimize their purchase decisions across time. The key constraint is a production function that allows for global and country-specific productivity shocks. If one assumes that productivity follows a random walk, then the solution to their optimization problem is (Glick and Rogoff, 1995, eqs. 15 and 17)

$$
\begin{aligned}
\Delta C A_{i t}^{*} & =\gamma_{0 i}+\gamma_{1 i} I_{i, t-1}+\gamma_{2 i} \widehat{\Pi}_{i t}^{c}+\gamma_{3 i} \widehat{\Pi}_{t}^{w}+\epsilon_{1 i t} \\
\Delta I_{i t} & =\beta_{0 i}+\beta_{1 i} I_{i, t-1}+\beta_{2 i} \widehat{\Pi}_{i t}^{c}+\beta_{3 i} \widehat{\Pi}_{t}^{w}+\epsilon_{2 i t},
\end{aligned}
$$

where $\Delta C A_{i t}^{*}=\Delta C A_{i t}-r C A_{i, t-1}, C A_{i t}$ is the current account in real terms of the ith country; $r$ is the real interest rate; $I_{i t}$ is private investment in real terms; a "へ" denotes a growth rate; $\Pi_{i t}^{c}$ is country-specific multifactor productivity following a random-walk process; $\Pi_{t}^{w}$ is world multifactor productivity; and $\epsilon_{j i t} \sim I N\left(0, \sigma_{i}\right), E\left(\epsilon_{1 i t} \cdot \epsilon_{2 i t}\right)=0$.

The framework of Glick and Rogoff offers several testable implications but I focus on two of them. First, increases in country-specific productivity reduce the current account $\left(\gamma_{2}<0\right)$ and raise private investment $\left(\beta_{2}>0\right)$. Second, increases in global productivity raise domestic private investment $\left(\beta_{3}>0\right)$ but do not affect the current account $\left(\gamma_{3}=0\right)$. 


\subsection{Data Considerations}

Following Glick and Rogoff, I use IMF data for current accounts, expressed in US dollars, convert them to local currency, and then deflate them by the GDP deflator to obtain $C A_{t}$. Again, following their paper, I use IMF data for private investment, expressed in local currency, and deflate them by the GDP deflator to obtain $I_{t}$. Based on these data, figure 1 confirms that movements in the current account and movements in private investment are inversely correlated, just as Glick and Rogoff show. Thus, the question is not whether developments since 1990 have undermined this inverse association but whether their model explains it.
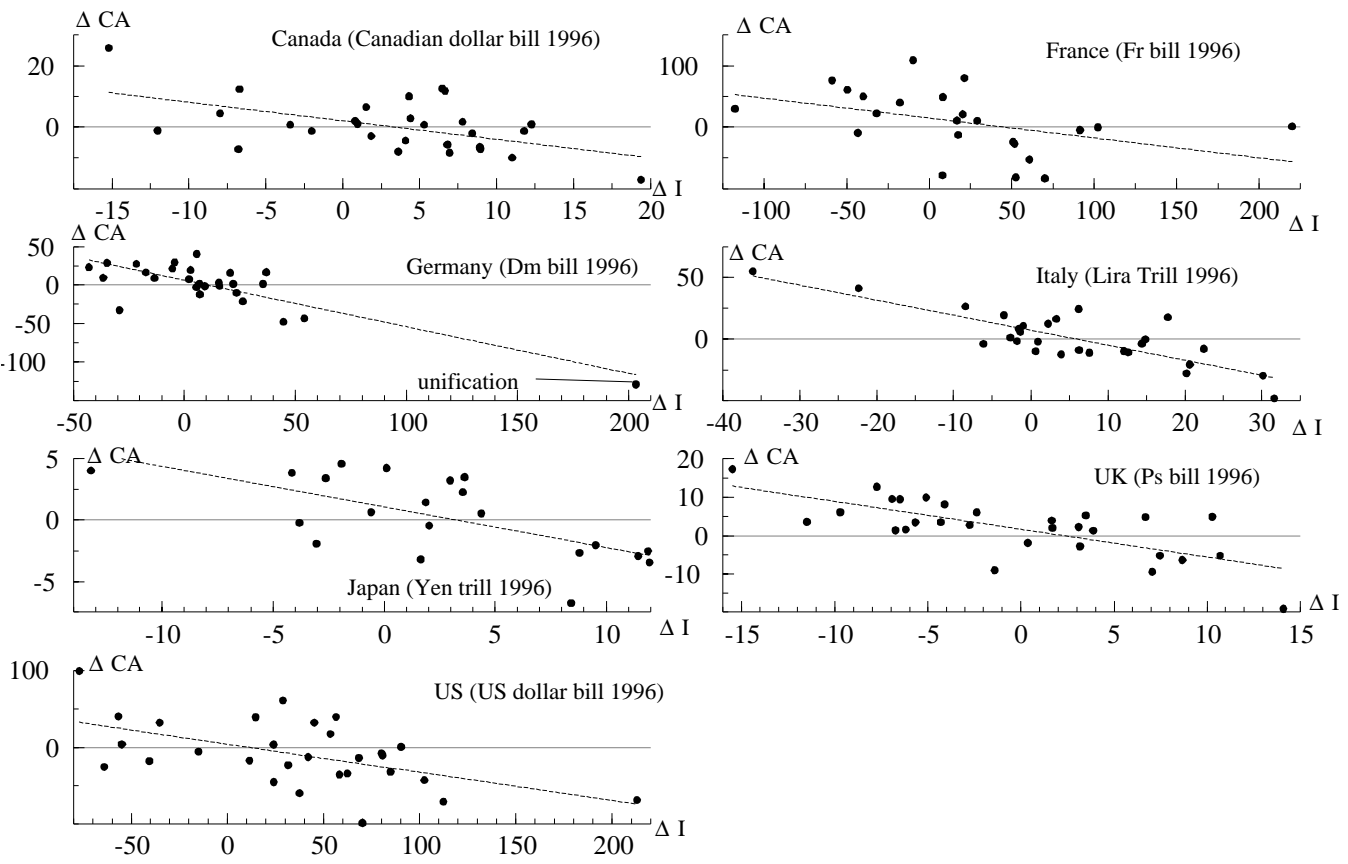

Figure 1: Changes in Private Investment and Current Accounts, local currency in real terms: 1970-1999. Selected Countries. Source: IMF.

Like Glick and Rogoff, I use data from Barro and Sala-i-Martin (1990) for the real interest rate, $r$, and extend the observations using the IMF's World Economic Outlook. With this interest rate, I find that differences between 
$\triangle C A_{i t}^{*}$ and $\Delta C A_{i t}$ are small, as Glick and Rogoff find. ${ }^{1}$

For productivity, Glick and Rogoff use BLS data for the manufacturing sector. I too use BLS data from the manufacturing sector and measure multifactor productivity growth as they did:

$$
\widehat{\Pi}_{i t}=\widehat{Y}_{i t}-w l_{i} \cdot \widehat{L}_{i t},
$$

where $Y_{i t}$ is the level of production, $L_{i t}$ is the level of labor hours; and $w l_{i}$ is the fixed labor share. ${ }^{2}$ This formulation assumes that movements in the productivity of the manufacturing sector are representative of movements in aggregate productivity. Also, by excluding the contribution of capital to the production process, the formulation assumes that capital accumulation is zero. Glick and Rogoff highlight these limitations and include a trend in equation (2) to capture the effects of capital accumulation. I follow their suggestion but I also address below how these assumptions introduce measurement errors relevant for parameter estimation.

The BLS productivity data of Glick and Rogoff span 1960 to 1990; the BLS productivity data that are now available span 1977 to 1998. This decline in sample size stems from the revisions to the US national income accounts that have introduced incompatibilities with other countries' data for dates prior to 1977; I address below questions involving sample size. ${ }^{3}$ Note, however, that I am using the data that Glick and Rogoff would be using if they were following today the empirical strategy they followed then.

Given these observations, I follow their definitions and measure countryspecific $\left(\widehat{\Pi}_{i t}^{c}\right)$ and world $\left(\widehat{\Pi}_{t}^{w}\right)$ productivity growth as

$$
\widehat{\Pi}_{i t}^{c}=\widehat{\Pi}_{i t}-\widehat{\Pi}_{t}^{w}
$$

and

$$
\widehat{\Pi}_{t}^{w}=\Sigma_{j} \omega_{i} \cdot \widehat{\Pi}_{j t},
$$

where $\omega_{i}$ is the 1975 GDP share of the ith country in the combined GDP of the G-7 countries; I use the values of $\omega_{i}$ reported by Glick and Rogoff.

\footnotetext{
${ }^{1}$ For 1970-1989, I use Barro and Sala-i-Martin (1990, p.22, actual world real interest rate); for 1990-93 I use the World Economic Outlook, May 1998, nominal rate (p.167) minus CPI inflation (p.156); for 1994-99 I use the IMF (2001), nominal rate (p.189) minus CPI inflation (p.177).

${ }^{2}$ I use the data from Glick and Rogoff (1995, footnote 12) for $w l_{i}$.

${ }^{3}$ I am grateful to Wolodar Lysko and Mike Harper, from the BLS, for clarifying the issue of cross-country comparability.
} 


\subsection{Empirical Results}

To ensure comparability with Glick and Rogoff, I use ordinary least squares and multiply the explanatory variables by the sample mean of GDP (Glick and Rogoff, 1995, footnote 17). Also, I include a dummy variable in the regressions for the United States to control for the surplus in the US current account in 1991 associated with Gulf-War unrequited transfers. I include the same dummy variable in the regressions for Germany to control for the effects of re-unification.

In terms of magnitudes, the estimated sensitivity of investment to productivity shocks $\left(\beta_{2}\right)$ is often times half of those reported by Glick and Rogoff (table 1). These reductions in magnitudes are relevant because they suggest the presence of biases from measurement errors. In terms of statistical significance, estimates based on the updated sample do not corroborate the findings of Glick and Rogoff. For example, estimates of the effect of countryspecific productivity shocks on the current account $\left(\gamma_{2}\right)$ are significant for two countries; Glick and Rogoff report estimates of $\gamma_{2}$ that are negative for all seven countries and significant for four of them. Furthermore, the updated estimates of $\beta_{2}$ are significant for two countries; Glick and Rogoff report estimates of $\beta_{2}$ that are positive for all seven countries and significant for five of them. Similarly, estimates of the effect of global productivity shocks on investment $\left(\beta_{3}\right)$ are, in general, statistically insignificant whereas Glick and Rogoff report significant estimates of $\beta_{3}$ for five countries.

\subsection{Data Revisions and Extensions}

One limitation of the findings of table 1 is that they do not differentiate whether the lack of empirical support stems from data revisions as such or from extending the data past 1990. To sort out the separate contributions of these two changes, I re-estimate the parameters of equations (1)-(2) with two samples:

Revised Sample: Original productivity data of Glick and Rogoff over 1961-77 combined with the revised observations over 1978-90. By retaining their sample size, I examine whether data revisions affect their conclusion. ${ }^{4}$

\footnotetext{
${ }^{4}$ The sample correlations for $\Pi_{i t}^{c}$ between the original and the revised data over 1978-90 are 0.83 for Canada, 0.93 for France, 0.92 for Germany, 0.66 for Japan, 0.92 for Italy, 0.89 for the United Kingdom, and 0.62 for the United States.
} 
Extended Sample: Original productivity data over 1961-77 combined with the revised observations over 1978-90 and the extended observations over 1991-98. Results based on the extended sample allow me to detect the importance of post-1990 developments while controlling for data definitions.

In terms of the magnitudes, the results show that data revisions reduce the sensitivity of investment to productivity shocks, $\beta_{2}$, (table 2 ). Using the extended sample lowers this sensitivity even more. In terms of statistical significance, reliance on the revised sample does not change, generally, the conclusion reached by Glick and Rogoff whereas reliance on the extended sample undermines the force of their findings.

Overall, then, the results of table 2 suggest that the findings of Glick and Rogoff are robust to data revisions as such but not to economic developments since 1990. However, before concluding that their finding is no longer relevant, I examine whether the lack of empirical support reported here is due to model misspecifications or to measurement errors.

\section{Respecification of Linkages}

\subsection{Model Misspecifications}

I consider several types of model misspecifications. The first one stems from excluding price effects in the model. To address this misspecification, I follow İşcan (2000) and reformulate the model as

$$
\begin{aligned}
\Delta C A_{i t}^{*} & =\gamma_{0 i}+\gamma_{1 i} I_{i, t-1}+\gamma_{2 i} \widehat{\Pi}_{i t}^{c}+\gamma_{3 i} \widehat{\Pi}_{t}^{w}+\gamma_{4 i} \widehat{P}_{i t}+\epsilon_{1 i t} \\
\Delta I_{i t} & =\beta_{0 i}+\beta_{1 i} I_{i, t-1}+\beta_{2 i} \widehat{\Pi}_{i t}^{c}+\beta_{3 i} \widehat{\Pi}_{t}^{w}+\beta_{4 i} \widehat{P}_{i t}+\epsilon_{2 i t} .
\end{aligned}
$$

Like İscan, I use two alternative measures of relative prices: either the terms of trade or the real effective exchange rate. ${ }^{5}$

A second source of model misspecification is the exclusion of fiscal shocks from (1) and (2) above. To allow for this type of shock, I follow Glick and

\footnotetext{
${ }^{5}$ İscan recognizes that tradeable and non-tradeable sectors have different productivities. Developing this data decomposition is beyond the scope of this paper. Indeed, İşcan's sample ends in 1987. Thus I assume that the effects of productivity shocks from these two sectors are equal to each other-that is, a one-good model. I am thankful to Talan İşcan for bringing this point to my attention.
} 
Rogoff (1995, footnote 23, page 177) and use

$$
\begin{aligned}
\Delta C A_{i t}^{*} & =\gamma_{0 i}+\gamma_{1 i} I_{i, t-1}+\gamma_{2 i} \widehat{\Pi}_{i t}^{c}+\gamma_{3 i} \widehat{\Pi}_{t}^{w}+\gamma_{4 i} \Delta G_{t}^{w}+\epsilon_{1 i t} \\
\Delta I_{i t} & =\beta_{0 i}+\beta_{1 i} I_{i, t-1}+\beta_{2 i} \widehat{\Pi}_{i t}^{c}+\beta_{3 i} \widehat{\Pi}_{t}^{w}+\beta_{4 i} \Delta G_{i t}^{c}+\epsilon_{2 i t}
\end{aligned}
$$

where $G_{t}^{w}=\Sigma_{j} \omega_{i} \cdot G_{j t}$, and $G_{j t}$ is the GDP share of government purchases (in current prices).

The third source of misspecification is the assumption that productivity follows a random walk. To address this misspecification, I assume that $\Pi_{i t}^{c}$ follows a stationary process and implement the solution developed by Glick and Rogoff (1995, eqs., 26-27):

$$
\begin{aligned}
\Delta C A_{i t}^{*} & =\gamma_{0 i}+\gamma_{1 i} I_{i, t-1}+\gamma_{20 i} \Pi_{i t}^{c}+\gamma_{21 i} \Pi_{i, t-1}^{c}+\gamma_{3 i} \widehat{\Pi}_{t}^{w}+\epsilon_{1 i t} \\
\Delta I_{i t} & =\beta_{0 i}+\beta_{1 i} I_{i, t-1}+\beta_{2 i} \widehat{\Pi}_{i t}^{c}+\beta_{3 i} \widehat{\Pi}_{t}^{w}+\epsilon_{2 i t},
\end{aligned}
$$

where $\gamma_{2}$ needs to be replaced with $\gamma_{20}$ for hypothesis testing. I also examine the cases arising from augmenting the case of stationary productivity with the allowance of either price effects or fiscal shocks:

$$
\begin{aligned}
\Delta C A_{i t}^{*} & =\gamma_{0 i}+\gamma_{1 i} I_{i, t-1}+\gamma_{20 i} \Pi_{i t}^{c}+\gamma_{21 i} \Pi_{i, t-1}^{c}+\gamma_{3 i} \widehat{\Pi}_{t}^{w}+\gamma_{4 i} Z_{c a, t}+\epsilon_{1 i t} \\
\Delta I_{i t} & =\beta_{0 i}+\beta_{1 i} I_{i, t-1}+\beta_{2 i} \widehat{\Pi}_{i t}^{c}+\beta_{3 i} \widehat{\Pi}_{t}^{w}+\beta_{4 i} Z_{I t}+\epsilon_{2 i t},
\end{aligned}
$$

where the terms $Z_{c a, t}$ and $Z_{I t}$ represent either the price-effect variable or the fiscal shock.

A fourth source of misspecification is the treatment of productivity as an exogenous variable; Glick and Rogoff note this limitation but do not endogenize productivity. To this end, I postulate that multifactor productivity growth follows Hall's markup model (Hall 1987) augmented by two factors from endogenous-growth models: the extent of research activities and capital accumulation. Specifically, I use ${ }^{6}$

$$
\widehat{\Pi}_{i t}=\eta_{0 i}+\eta_{1 i} R_{i t}+\eta_{2 i} \frac{Y_{i t}}{Y_{i t}^{*}}+\eta_{3 i} \Delta I_{i t}+\eta_{4 i} I_{i, t-1}+\epsilon_{3 i t},
$$

\footnotetext{
${ }^{6}$ I am following the work of Stiroh (2001) and Basu and Fernald (2001). Hulten (2001) reviews the literature on the determinants of multifactor productivity growth.
} 
where $R_{i t}$ represents the extent of research activity and $\frac{Y_{i t}}{Y_{i t}^{*}}$ is the OECD's gap between actual and potential GDP. ${ }^{7}$ With this formulation, I reformulate the model of Glick and Rogoff as

$$
\begin{aligned}
\Delta C A_{i t}^{*} & =\gamma_{0 i}+\gamma_{1 i} I_{i, t-1}+\gamma_{2 i} \widehat{\Pi}_{i t}^{c}+\gamma_{3 i} \widehat{\Pi}_{t}^{w}+\epsilon_{1 i t} \\
\Delta I_{i t} & =\beta_{0 i}+\beta_{1 i} I_{i, t-1}+\beta_{2 i} \widehat{\Pi}_{i t}^{c}+\beta_{3 i} \widehat{\Pi}_{t}^{w}+\epsilon_{2 i t} \\
\widehat{\Pi}_{i t}^{c} & =\widehat{\Pi}_{i t}-\widehat{\Pi}_{t}^{w} \\
\widehat{\Pi}_{i t} & =\eta_{0 i}+\eta_{1 i} R_{i t}+\eta_{2 i} \frac{Y_{i t}}{Y_{i t}^{*}}+\eta_{3 i} \Delta I_{i t}+\eta_{4 i} I_{i, t-1}+\epsilon_{3 i t},
\end{aligned}
$$

where $\epsilon_{i t}^{\prime}=\left(\epsilon_{1 i t} \epsilon_{2 i t} \epsilon_{3 i t}\right)^{\sim} N\left(0, \Omega_{i}\right)$. Pursuing this modeling alternative raises, however, two difficulties. First, the formulation for productivity, equation (17), could be misspecified and thus the parameter estimates of the other equations could be biased. Second, even if equation (17) were correctly specified, there is no a-priori reason to believe that it would leave the derivation of equations (14) and (15) intact. Thus the results from this alternative specification should be treated as tentative.

\subsection{Measurement Errors}

One of the econometric implications of measurement error in the explanatory variables is the introduction of a downward bias in the coefficient estimates. This pattern is precisely what appears in table 2 and thus I consider four sources of measurement errors.

The first one is the estimation of global productivity shocks treating the GDP shares as fixed in 1975. As an alternative, I allow the GDP shares to change over time. Thus the measure of global productivity growth becomes $\widehat{\Pi}_{t}^{w}=\Sigma_{j} \omega_{j t} \cdot \widehat{\Pi}_{j t}$, where $\omega_{j t}$ is the GDP share of the $j t h$ country, at time $t$, in the combined GDP of the G-7 countries.

A variant of this alternative involves asking whether the results are sensitive to defining the world as the G-7 countries. Indeed, the difference between

\footnotetext{
${ }^{7}$ Data for $R_{i t}$ come from the OECD Research and Development Expenditure and Industry, 197\%-1998 (OECD, 2000 edition, Paris); data for $\frac{Y_{i t}}{Y_{i t}^{*}}$ come from the OECD's measure of output gaps available in the Economic Outlook June 2001.
} 
country-specific and global productivity shocks hinges on how one defines the world. Thus I expand the definition of the world to include Australia, the Netherlands, and Norway, countries that have experienced gains in productivity recently (see Gust and Marquez, 2000). To implement this possibility, I redefine global productivity growth as $\widehat{\Pi}_{t}^{w}=\Sigma_{j=1}^{10} \vartheta_{j t} \cdot \widehat{\Pi}_{j t}$, where $\vartheta_{j t}$ is the GDP share of the $j t h$ country, at time $t$, in the combined GDP of the G-7 countries, Australia, Netherlands, and Norway.

The second source of measurement error is the redefinition of investment in the national accounts to include firms' spending on computers and software; the data used by Glick and Rogoff pre-date such a redefinition. This change is important because the substantial declines in the prices of computers and software have induced a sharp decline in the relative price of investment. Thus deflating nominal investment with the GDP deflator, as in Glick and Rogoff, does not fully capture the decline in the price of investment and understates movements in real investment. ${ }^{8}$ To avoid this bias, I express $\Delta I_{i t}$ and $\Delta C A_{i t}^{*}$ relative to real GDP. ${ }^{9}$

The third source is the use of productivity in manufactures as a proxy for productivity for the whole economy. Indeed, the GDP share of the manufacturing sector for all G-7 countries has declined noticeably:

\begin{tabular}{cccccccc}
\multicolumn{7}{c}{ GDP Share of Manufacturing Sector (\%) } \\
\hline \hline & Canada & France & Germany & Italy & Japan & UK & US \\
1970 & 19 & 26 & 37 & 27 & 35 & 29 & 24 \\
1980 & 17 & 24 & 31 & 28 & 29 & 23 & 21 \\
1990 & 15 & 21 & 30 & 22 & 27 & 20 & 18 \\
1997 & 16 & 19 & 22 & 20 & 24 & 17 & 17 \\
\hline \hline
\end{tabular}

Such a decline suggests that movements in productivity in manufactures are not representative of movements in overall productivity. As an alternative, I use data from Gust and Marquez (2000) who estimate productivity for the business sector from 1980-1999, a span quite comparable to that now offered by the BLS for the manufacturing sector.

\footnotetext{
${ }^{8}$ I am grateful to Reuven Glick for pointing out this possibility.

${ }^{9}$ The un-scaled measure of $\Delta I_{i t}$ is $\Delta I_{i t}=\Delta\left(\frac{I_{i t}^{n}}{P_{y t}}\right)$, where the superscript $n$ indicates nominal terms and $P_{y t}$ denotes the GDP deflator. If prices are sticky, then $\Delta\left(\frac{I_{i t}^{n}}{P_{y t}}\right) \simeq \frac{\Delta I_{i t}^{n}}{P_{y t}}$. Scaling $\Delta I_{i t}$ by real GDP yields $\frac{\Delta I_{i t}}{Y_{t}}=\frac{1}{Y_{t}} \frac{\Delta I_{i t}^{n}}{P_{y t}}=\frac{\Delta I_{i t}^{n}}{Y_{t}^{n}}$.
} 
I want to emphasize that Glick and Rogoff take pains in evaluating the merits of using alternative measures of productivity. Specifically, they consider the measure for manufactures, as offered by the BLS, and the measure for the business sector, as offered by the OECD. They decide to use productivity data for the manufacturing sector because of a longer span: 1960-1990 for the BLS data versus 1971-1985 for the OECD data.

The final source of measurement error is the exclusion of the role of capital accumulation in measuring multifactor productivity, equation (3). To address this limitation I use the data of Gust and Marquez (2000) who measure multifactor productivity growth for the business sector of the ith country as

$$
\widehat{\Pi}_{i t}=\widehat{Y}_{i t}-\left[w l_{i t} \cdot \widehat{L}_{i t}+\left(1-w l_{i t}\right) \cdot \widehat{K}_{i t}\right]
$$

where $K_{i t}$ is the capital stock. As long as $\widehat{K}_{i t} \neq 0$, ignoring the influence of capital will induce measurement errors.

In principle, one can study the effects of using data from the business sector while excluding the role of capital stock so as to identify the contribution of the latter. In practice, however, several empirical studies document the importance of movements in capital for measuring productivity in the business sector. ${ }^{10}$ Thus, for the sake of brevity, the empirical results reported below combine the third and fourth sources of measurement errors.

\subsection{Empirical Results Redux}

Table 3 reports the FIML estimates for the country-specific effects, $\gamma_{2}$ and $\beta_{2}$, for each of the alternative formulations using productivity data from two sectors: the manufacturing and business sectors. The estimated effects of country-specific shocks based on manufacturing data support neither $\gamma_{2}<0$ nor $\beta_{2}>0$; the exceptions are the estimate of $\gamma_{2}$ for the United Kingdom and the estimate of $\beta_{2}$ for France and Japan. This lack of support is robust to the treatment of productivity as a stationary process and to the allowance of either price effects or fiscal shocks. For Canada, however, controlling for fiscal shocks matters for the estimate of $\gamma_{2}$.

With productivity data from the business sector, the estimates of $\gamma_{2}$ are negative and strongly significant for France, Germany, Japan, and the United States; estimates of $\beta_{2}$ are positive and strongly significant for the same four countries. This empirical support is robust to the allowance of

\footnotetext{
${ }^{10}$ See Gordon (2000), Oliner and Sichel (2000), and Gust and Marquez (2000).
} 
either price effects or fiscal shocks and to the treatment of productivity as a stationary process. An implication of this finding is that the lack of statistical significance found in table 1 is not due to a reduced sample size, as both sets of estimates rest on comparable sample sizes. Overall, the results indicate that if one uses the updated sample with business-sector productivity data, then movements in country-specific productivity explain the inverse association between private investment and the current account, as Glick and Rogoff found.

Table 4 reports the FIML estimates of global effects for the formulations using the GDP-scaled data. For data from the manufacturing sector, the estimates do not support $\beta_{3}>0$ save for the United Kingdom; this result is robust to the allowance of both price effects and fiscal shocks and to the treatment of productivity as a stationary process. For data from the business sector, estimates of $\beta_{3}$ are positive and strongly significant for France, Germany, Japan, and the United Kingdom; this support is robust to the allowance of either price or fiscal effects and to the treatment of productivity as a stationary process. Note that, regardless of productivity data, the results support the hypothesis that global productivity shocks do not affect the current account, $\gamma_{3}=0$, as Glick and Rogoff find.

Table 5 reports the FIML estimates for the case where world income includes Australia, Netherlands, and Norway; the results suggest that this extension has virtually no effect on the results. This robustness is not surprising as it reflects the similarity of the productivity performance of the three additional countries with the aggregate of G-7 countries with little change in measured global productivity growth.

Table 6 reports the estimates for the parameters of equations (14)-(17) using FIML and productivity data from the business sector. I consider four alternative measures of research activities:

$R_{1}: \mathrm{R} \& \mathrm{D}$ expenditures as a share of GDP, current prices

$R_{2}$ : Cumulated R\&D expenditures as a share of GDP, current prices

$R_{3}$ : Number of researchers per capita

$R_{4}$ : Number of scientists and engineers in R\&D sector per capita

Unfortunately, the OECD data for these four measures are available only for Canada, France, Japan, and the United Kingdom. Data for $R_{3}$ are not available for Germany and Italy, data for $R_{4}$ are not available for Germany and the United States. 
The results for France and Japan are quite promising. First, the estimates strongly support changes in productivity as the explanation for the inverse association between private investments and current accounts. Specifically, the estimates of $\gamma_{2}$ are negative and strongly significant; the estimates of $\beta_{2}$ are positive and strongly significant. Taken together, these findings support the view of productivity shocks as inducing the inverse association between current account and private investments. Second, private investment has a direct, and significant effect, on business sector's multifactor productivity growth $\left(\eta_{3}\right.$ and $\left.\eta_{4}\right)$.

The results for other countries are disappointing: estimates of $\gamma_{2}$ and $\beta_{2}$ change in both magnitude and statistical significance. One explanation for this parameter sensitivity is that the model of Glick and Rogoff (eqs. 1 and 2) need not be invariant to the modeling of productivity whereas I have assumed such an invariance. As an alternative, and even if this invariance were correct, there is no guarantee that the equation for productivity growth that I use is correctly specified. Misspecifying the equation for productivity will bias the coefficients of the Glick-Rogoff model.

\section{Conclusions}

The existing consensus on the role of country-specific productivity shocks in explaining movements in private investment and current accounts rests not on theoretical reasoning but on empirical evidence. And that evidence rests on data for productivity from the manufacturing sector through 1990. The question I ask is whether that consensus is robust to developments since then.

Several developments motivate my interest in addressing this question. First, the definition of investment in the national income accounts now includes firms' spending on computers and software; the data used by Glick and Rogoff pre-date such a redefinition. Second, the substantial expansion of the information technology (IT) sector, by globalizing the production of manufactures, could erode the distinction between country-specific and global productivity shocks in manufactures, a distinction central to the professional consensus. But even in the absence of globalization, the expansion of the information-technology sector remains relevant because it is reflected in expenditures in software and hardware which, because of definitional changes, may induce movements in private investment. 
These two developments invite an empirical re-examination of their results and that is what I do here. My results suggest five conclusions. First, recent data revisions leave the conclusion of Glick and Rogoff intact. Second, extending and updating their sample weakens their result considerably. This lack of empirical support is also present even if one were to address known model misspecifications. Third, addressing this lack of empirical support involves recognizing the role of capital inputs in measuring multifactor productivity and the decline in the informational content of productivity in the manufacturing sector as a proxy for overall productivity. After addressing these two limitations, I find that movements in productivity explain both investment and the current account, just as Glick and Rogoff find.

Fourth, and looking forward to the next modeling phase, expanding the definition of the world to include additional OECD countries left the results unchanged. This result does not, however, preclude informational gains from including, say, developing countries in the definition of the world. This extension is likely to yield interesting surprises relevant for understanding the international repercussions of productivity shocks. Finally, endogenizing productivity growth in the context of the Glick-Rogoff model yields, by and large, disappointing results. For France and Japan, however, the results are tantalizing enough to motivate further work in this direction.

\section{References}

[1] Barro, R. and X. Sala-i-Martin, 1990, "World Real Interest Rates," in O. Blanchard and S. Fischer, (eds.), NBER Macroeconomics Annual 1990 (NBER/MIT Press, Cambridge, MA).

[2] Basu, S. and J. Fernald, 2001, "Why is Productivity Pro-cyclical? Why Do We Care?" in C. Hulten, E. Dean, and M. Harper (eds.) New Developments in Productivity Analysis, U. of Chicago Press, 225-302.

[3] Glick, R. and K. Rogoff, 1995, "Global versus Country-specific Productivity Shocks and the Current Account," Journal of Monetary Economics, 35, 159-192.

[4] Gordon, R., 2000, "Does the New Economy Measure Up to the Great Inventions of the Past?" Journal of Economic Perspectives, 14, 49-74. 
[5] Gust, C. and J. Marquez, 2000, "Productivity Developments Abroad," Federal Reserve Bulletin, 86, 665-681 (Federal Reserve Board, Washington DC).

[6] Hall, R., 1987, "Productivity and the Business Cycle," CarnegieRochester Conference Series, 27, 412-444.

[7] Hulten, C., 2001, "Total Factor Productivity: A Short Biography," in C. Hulten, E. Dean, and M. Harper. (eds.) New Developments in Productivity Analysis, U. of Chicago Press, 1-47.

[8] International Monetary Fund, 2001, World Economic Outlook, October (International Monetary Fund, Washington DC) <http://www.imf.org/external/pubs/ft/weo/2001/02/index.htm>

[9] İşcan, T., 2000, "The Terms of Trade, Productivity Growth and the Current Account," Journal of Monetary Economics, 45, 587-611.

[10] Oliner, S. and D. Sichel, "The Resurgence of Growth in the Late 1990s: Is Information the Story?" Journal of Economic Perspectives, 14, 3-22.

[11] Stiroh, K., 2001, "What Drives Productivity Growth?" FRBNY Economic Policy Review, March, 37-59. 
Table 1: Parameter Estimates-OLS ${ }^{a}$

Original and Updated Data

$$
\begin{aligned}
\Delta C A_{i t}^{*} & =\gamma_{0 i}+\gamma_{1 i} I_{i, t-1}+\gamma_{2 i} \widehat{\Pi}_{i t}^{c}+\gamma_{3 i} \widehat{\Pi}_{i t}^{w}+\epsilon_{1 i t} \\
\Delta I_{i t} & =\beta_{0 i}+\beta_{1 i} I_{i, t-1}+\beta_{2 i} \widehat{\Pi}_{i t}^{c}+\beta_{3 i} \widehat{\Pi}_{i t}^{w}+\beta_{4 i} \text { Trend }+\epsilon_{2 i t}
\end{aligned}
$$

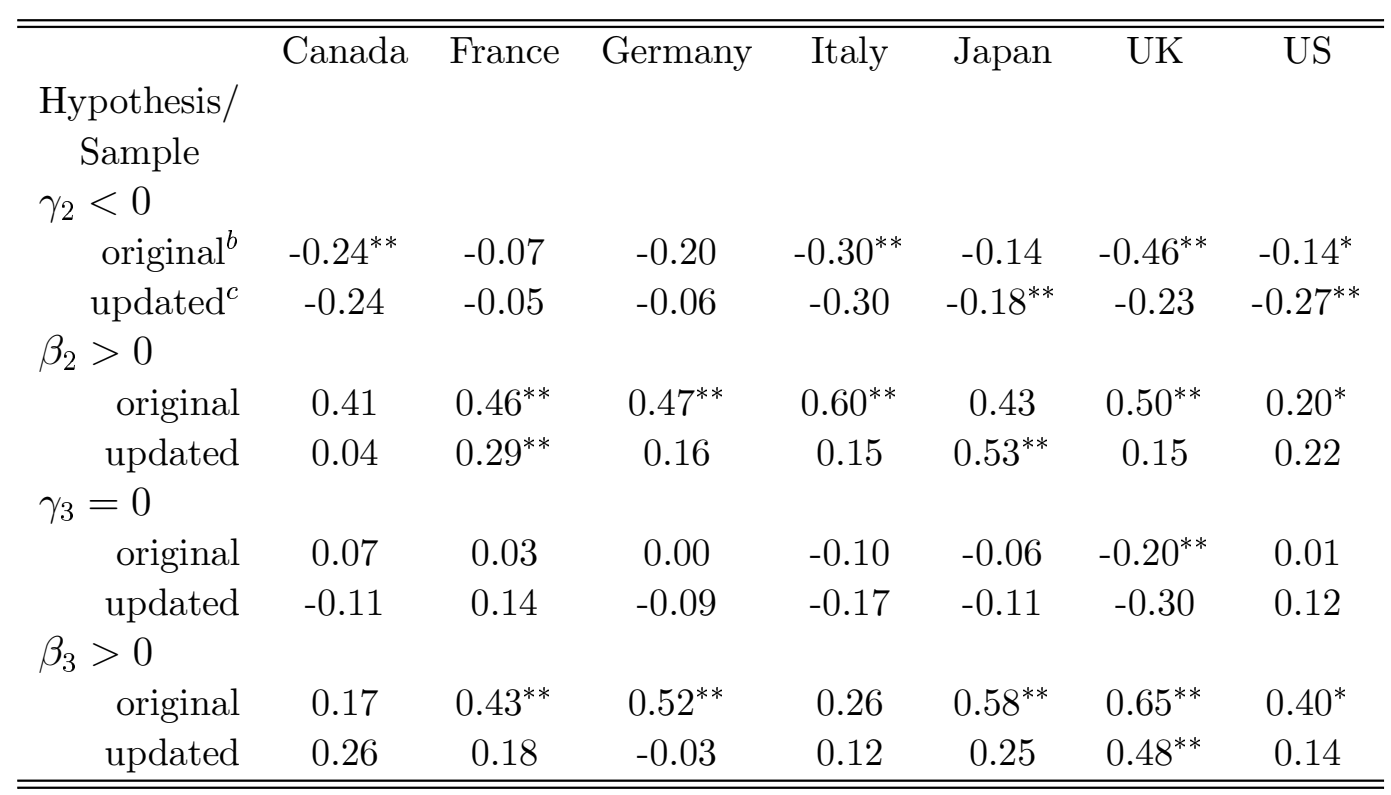

${ }^{a}$ Estimates with Newey-West correction; ${ }^{* *}$ significant at the $5 \%$ level; ${ }^{*}$ significant at the $10 \%$ level.

${ }^{b}$ original: Estimates from Glick and Rogoff (1995, table 3, p.175).

${ }^{c}$ updated: Recently released data for 1977-1998. 
Table 2: Parameter Estimates-OLS ${ }^{a}$

Robustness to Alternative Samples

$$
\begin{aligned}
\Delta C A_{i t}^{*} & =\gamma_{0 i}+\gamma_{1 i} I_{i, t-1}+\gamma_{2 i} \widehat{\Pi}_{i t}^{c}+\gamma_{3 i} \widehat{\Pi}_{i t}^{w}+\epsilon_{1 i t} \\
\Delta I_{i t} & =\beta_{0 i}+\beta_{1 i} I_{i, t-1}+\beta_{2 i} \widehat{\Pi}_{i t}^{c}+\beta_{3 i} \widehat{\Pi}_{i t}^{w}+\beta_{4 i} \text { Trend }+\epsilon_{2 i t}
\end{aligned}
$$

\begin{tabular}{cccccccc}
\hline \hline & Canada & France & Germany & Italy & Japan & UK & US \\
Hypothesis/ & & & & & & & \\
Sample & & & & & & & \\
$\gamma_{2}<0$ & & & & & & & \\
original $^{b}$ & $-0.24^{* *}$ & -0.07 & -0.20 & $-0.30^{* *}$ & -0.14 & $-0.46^{* *}$ & $-0.14^{*}$ \\
revised $^{c}$ & -0.41 & -0.08 & -0.16 & $-0.32^{* *}$ & $-0.14^{* *}$ & $-0.62^{* *}$ & 0.10 \\
extended $^{d}$ & -0.30 & -0.02 & -0.12 & $-0.23^{* *}$ & $-0.12^{* *}$ & $-0.35^{* *}$ & 0.33 \\
updated $^{e}$ & -0.24 & -0.05 & -0.06 & -0.30 & $-0.18^{* *}$ & -0.23 & $-0.27^{* *}$ \\
$\beta_{2}>0$ & & & & & & & \\
original & 0.41 & $0.46^{* *}$ & $0.47^{* *}$ & $0.60^{* *}$ & 0.43 & $0.50^{* *}$ & $0.20^{*}$ \\
revised & 0.09 & $0.47^{* *}$ & $0.40^{* *}$ & $0.23^{* *}$ & $0.38^{* *}$ & $0.52^{* *}$ & 0.16 \\
extended & 0.12 & 0.24 & 0.21 & $0.23^{* *}$ & $0.44^{* *}$ & 0.14 & 0.33 \\
updated & 0.04 & $0.29^{* *}$ & 0.16 & 0.15 & $0.53^{* *}$ & 0.15 & 0.22 \\
$\gamma_{3}=0$ & & & & & & & \\
original & 0.07 & 0.03 & 0.00 & -0.10 & -0.06 & $-0.20^{* *}$ & 0.01 \\
revised & 0.14 & -0.03 & -0.01 & -0.18 & -0.06 & -0.21 & 0.01 \\
extended & 0.12 & 0.03 & -0.02 & -0.18 & -0.05 & -0.18 & 0.02 \\
updated & -0.11 & 0.14 & -0.09 & -0.17 & -0.11 & -0.30 & 0.12 \\
$\beta_{3}>0$ & & & & & & & \\
original & 0.17 & $0.43^{* *}$ & $0.52^{* *}$ & 0.26 & $0.58^{* *}$ & $0.65^{* *}$ & 0.40 \\
revised & 0.09 & $0.41^{* *}$ & $0.38^{* *}$ & 0.03 & $0.56^{* *}$ & $0.41^{* *}$ & $0.30^{* *}$ \\
extended & 0.13 & 0.21 & $0.27^{* *}$ & 0.07 & $0.24^{* *}$ & $0.38^{* *}$ & $0.31^{* *}$ \\
updated & 0.26 & 0.18 & -0.03 & 0.12 & 0.25 & $0.48^{* *}$ & 0.14 \\
\hline \hline
\end{tabular}

${ }^{a}$ Estimates with Newey-West correction; ${ }^{* *}$ significant at the $5 \%$ level; ${ }^{*}$ significant at the $10 \%$ level.

${ }^{b}$ original: Estimates from Glick and Rogoff (1995, table 3, p.175).

${ }^{c}$ revised: sample for 1960-1977 from Glick and Rogoff expanded with data revisions over 1978-1990.

${ }^{d}$ extended: sample for 1960-1977 from Glick and Rogoff with revisions over 197890, and extensions through 1998.

e updated: Recently released data for 1977-1998; no data from Glick and Rogoff. 
Table 3: Parameter Estimates FIML - 1980-1998

Sensitivity to Data and to Modeling Assumptions ${ }^{1}$

\begin{tabular}{|c|c|c|c|c|c|c|c|c|}
\hline & \multicolumn{4}{|c|}{ Manufacturing-Sector Data } & \multicolumn{4}{|c|}{ Business-Sector Data } \\
\hline & \multicolumn{2}{|c|}{$\gamma_{2}$} & \multicolumn{2}{|c|}{$\beta_{2}$} & \multicolumn{2}{|c|}{$\gamma_{2}$} & \multicolumn{2}{|c|}{$\beta_{2}$} \\
\hline & $\begin{array}{l}\text { Random } \\
\text { Walk }\end{array}$ & Stationary & $\begin{array}{l}\text { Random } \\
\text { Walk }\end{array}$ & Stationary & $\begin{array}{c}\text { Random } \\
\text { Walk }\end{array}$ & Stationary & $\begin{array}{l}\text { Random } \\
\text { Walk }\end{array}$ & Stationary \\
\hline \multicolumn{9}{|l|}{ Canada } \\
\hline This Study & -0.27 & -0.30 & 0.03 & 0.06 & -0.25 & -0.25 & 0.04 & 0.04 \\
\hline$\&$ Terms of Trade & -0.28 & -0.25 & 0.04 & 0.03 & -0.26 & -0.26 & 0.04 & 0.04 \\
\hline \& Real Exchg. Rate & -0.33 & -0.38 & 0.06 & 0.11 & -0.26 & -0.26 & 0.08 & 0.08 \\
\hline \& Fiscal Shocks & $-0.63 * *$ & $-0.63^{*}$ & 0.05 & 0.08 & -0.76 & -0.11 & 0.23 & 0.24 \\
\hline \multicolumn{9}{|l|}{ France } \\
\hline This Study & -0.09 & -0.14 & $0.33 * *$ & $0.32 * *$ & $-0.47 * *$ & -0.21 & $0.73 * *$ & $0.75 * *$ \\
\hline$\&$ Terms of Trade & -0.09 & -0.13 & $0.32 *$ & 0.32 & $-0.47 * *$ & -0.21 & $0.73 * *$ & $0.74 * *$ \\
\hline \& Real Exchg. Rate & -0.11 & -0.22 & $0.37 * *$ & $0.36^{*}$ & $-0.54 * *$ & -0.24 & $0.78 * *$ & $0.78 * *$ \\
\hline \& Fiscal Shocks & -0.09 & -0.14 & $0.33 * *$ & $0.29 *$ & $-0.47 *$ & -0.21 & $0.74 * *$ & $0.77 * *$ \\
\hline \multicolumn{9}{|l|}{ Germany } \\
\hline This Study & -0.05 & 0.06 & 0.11 & 0.07 & $-0.55 * *$ & $-0.50 * *$ & $0.56 * *$ & $0.52 * *$ \\
\hline$\&$ Terms of Trade & -0.05 & 0.06 & 0.11 & 0.05 & $-0.54 * *$ & -0.44 & $0.62 * *$ & $0.59 * *$ \\
\hline \& Real Exchg. Rate & -0.11 & -0.02 & 0.17 & 0.13 & $-0.52 * *$ & $-0.51 * *$ & $0.52 * *$ & $0.54 * *$ \\
\hline \& Fiscal Shocks & 0.01 & 0.07 & 0.09 & 0.05 & $-0.66^{* *}$ & $-0.60 *$ & $0.46^{* *}$ & $0.36^{*}$ \\
\hline \multicolumn{9}{|l|}{ Italy } \\
\hline This Study & -0.25 & -0.22 & 0.12 & 0.13 & -0.20 & 0.04 & 0.06 & 0.08 \\
\hline$\&$ Terms of Trade & -0.27 & -0.24 & 0.13 & 0.13 & -0.18 & 0.22 & 0.06 & 0.08 \\
\hline \& Real Exchg. Rate & -0.22 & -0.19 & 0.11 & 0.11 & -0.38 & -0.21 & 0.21 & 0.29 \\
\hline \& Fiscal Shocks & -0.33 & -0.29 & 0.11 & 0.12 & -0.19 & 0.30 & 0.10 & 0.13 \\
\hline \multicolumn{9}{|l|}{ Japan } \\
\hline This Study & -0.13 & -0.07 & $0.48 * *$ & $0.49^{* *}$ & $-0.34 * *$ & $-0.39 * *$ & $1.04 * *$ & $1.03 * *$ \\
\hline$\&$ Terms of Trade & -0.12 & -0.09 & $0.52 * *$ & $0.53 * *$ & $-0.32 * *$ & $-0.36^{*}$ & $1.06 * *$ & $1.04 * *$ \\
\hline \& Real Exchg. Rate & -0.12 & -0.09 & $0.52 * *$ & $0.53 * *$ & $-0.33 * *$ & $-0.38 * *$ & $1.02 * *$ & $1.02 * *$ \\
\hline \& Fiscal Shocks & -0.13 & -0.07 & $0.49 * *$ & $0.49 * *$ & $-0.36^{* *}$ & $-0.35^{*}$ & $1.05^{* *}$ & $1.04 * *$ \\
\hline \multicolumn{9}{|l|}{ UK } \\
\hline This Study & $-0.40 * *$ & $-0.39 * *$ & 0.29 & 0.26 & -0.06 & 0.07 & -0.09 & 0.02 \\
\hline$\&$ Terms of Trade & $-0.39^{*}$ & $-0.39 *$ & 0.30 & 0.28 & -0.02 & 0.07 & -0.13 & 0.01 \\
\hline \& Real Exchg. Rate & $-0.39 *$ & $-0.35 * *$ & 0.31 & 0.28 & 0.07 & 0.08 & -0.05 & 0.15 \\
\hline \& Fiscal Shocks & $-0.45^{*}$ & $-0.43^{*}$ & 0.35 & 0.34 & 0.13 & -0.28 & -0.02 & 0.09 \\
\hline \multicolumn{9}{|l|}{ US } \\
\hline This Study & -0.25 & -0.10 & 0.20 & 0.21 & $-0.61 * *$ & $-0.79 * *$ & $0.60 * *$ & $0.60 *$ \\
\hline$\&$ Terms of Trade & -0.23 & -0.09 & 0.17 & 0.18 & $-0.64 * *$ & $-0.87 * *$ & $0.58^{*}$ & $0.58 *$ \\
\hline \& Real Exchg. Rate & $-0.25^{*}$ & -0.11 & 0.20 & 0.21 & $-0.58 * *$ & $-0.76 * *$ & $0.54 *$ & $0.55^{*}$ \\
\hline \& Fiscal Shocks & -0.24 & -0.08 & 0.20 & 0.25 & $-0.69 * *$ & $-0.79 * *$ & $0.58 *$ & $0.58 *$ \\
\hline
\end{tabular}

${ }^{1}$ Estimates based on re-scaled data for changes of current account and private investment.

* Statistically significant at the $10 \%$ level; ** statistically significant at the $5 \%$ level. 
Table 4: Parameter Estimates of Global Effects; FIML - 1980-1998 Sensitivity to Data and to Modeling Assumptions ${ }^{1}$

\begin{tabular}{|c|c|c|c|c|c|c|c|c|}
\hline & \multicolumn{4}{|c|}{ Manufacturing-Sector Data } & \multicolumn{4}{|c|}{ Business-Sector Data } \\
\hline & \multicolumn{2}{|c|}{$\gamma_{3}$} & \multicolumn{2}{|c|}{$\beta_{3}$} & \multicolumn{2}{|r|}{$\gamma_{3}$} & \multicolumn{2}{|c|}{$\beta_{3}$} \\
\hline & $\begin{array}{l}\text { Random } \\
\text { Walk }\end{array}$ & Stationary & $\begin{array}{c}\text { Random } \\
\text { Walk }\end{array}$ & Stationary & $\begin{array}{c}\text { Random } \\
\text { Walk }\end{array}$ & Stationary & $\begin{array}{c}\text { Random } \\
\text { Walk }\end{array}$ & Stationary \\
\hline \multicolumn{9}{|l|}{ Canada } \\
\hline This Study & 0.03 & -0.03 & 0.28 & 0.33 & -1.01 & -1.03 & 0.79 & 0.79 \\
\hline$\&$ Terms of Trade & 0.03 & -0.17 & 0.22 & 0.44 & -1.11 & -1.17 & 0.72 & 0.72 \\
\hline \& Real Exchg. Rate & 0.12 & 0.10 & 0.23 & 0.24 & -1.00 & -1.03 & 0.78 & 0.78 \\
\hline \& Fiscal Shocks & -0.53 & -0.16 & 0.28 & 0.31 & $-1.81 * *$ & $-1.94 * *$ & 0.78 & 0.82 \\
\hline \multicolumn{9}{|l|}{ France } \\
\hline This Study & 0.01 & -0.01 & 0.29 & 0.30 & 0.04 & 0.28 & $0.92 *$ & $0.97 *$ \\
\hline$\&$ Terms of Trade & 0.06 & 0.04 & 0.29 & 0.30 & 0.04 & 0.28 & $0.92 *$ & $0.96 *$ \\
\hline \& Real Exchg. Rate & -0.04 & -0.10 & 0.36 & 0.37 & -0.02 & 0.26 & $0.97^{*}$ & $1.00 *$ \\
\hline \& Fiscal Shocks & 0.01 & -0.01 & 0.29 & 0.30 & 0.04 & 0.29 & $0.91^{*}$ & $0.97 *$ \\
\hline \multicolumn{9}{|l|}{ Germany } \\
\hline This Study & -0.20 & -0.14 & 0.09 & 0.07 & -0.17 & -0.17 & $0.70 * *$ & $0.71 * *$ \\
\hline$\&$ Terms of Trade & -0.21 & -0.12 & 0.09 & 0.03 & -0.16 & -0.12 & $0.77 * *$ & $0.76^{* *}$ \\
\hline \& Real Exchg. Rate & $-0.33^{*}$ & -0.26 & 0.21 & 0.17 & -0.27 & -0.27 & $0.86^{* *}$ & $0.88 * *$ \\
\hline \& Fiscal Shocks & -0.18 & -0.14 & 0.09 & 0.07 & -0.15 & -0.13 & $0.72 * *$ & $0.73 * *$ \\
\hline \multicolumn{9}{|l|}{ Italy } \\
\hline This Study & -0.34 & -0.34 & 0.12 & 0.13 & -0.28 & -0.16 & 0.24 & 0.24 \\
\hline$\&$ Terms of Trade & -0.30 & -0.29 & 0.12 & 0.14 & -0.27 & -0.08 & 0.23 & 0.24 \\
\hline \& Real Exchg. Rate & -0.35 & -0.35 & 0.16 & 0.17 & -0.05 & 0.10 & 0.04 & 0.03 \\
\hline \& Fiscal Shocks & -0.37 & -0.36 & 0.15 & 0.16 & -0.28 & -0.05 & 0.19 & 0.17 \\
\hline \multicolumn{9}{|l|}{ Japan } \\
\hline This Study & -0.12 & -0.06 & 0.29 & 0.26 & -0.19 & -0.15 & $1.19 * *$ & $1.16^{* *}$ \\
\hline$\&$ Terms of Trade & -0.11 & -0.09 & 0.35 & 0.32 & -0.18 & -0.12 & $1.18^{* *}$ & $1.18^{* *}$ \\
\hline \& Real Exchg. Rate & -0.12 & -0.08 & 0.30 & 0.28 & -0.17 & -0.14 & $1.18 * *$ & $1.15^{* *}$ \\
\hline \& Fiscal Shocks & -0.10 & -0.04 & 0.28 & 0.26 & -0.16 & -0.12 & $1.19 * *$ & $1.13 * *$ \\
\hline \multicolumn{9}{|l|}{ UK } \\
\hline This Study & -0.37 & -0.38 & $0.75 * *$ & $0.69 * *$ & -0.62 & -0.65 & $0.98^{*}$ & $1.04 * *$ \\
\hline$\&$ Terms of Trade & -0.40 & -0.41 & $0.77 * *$ & $0.73 * *$ & -0.59 & -0.64 & $0.95^{*}$ & $1.04 *$ \\
\hline \& Real Exchg. Rate & -0.37 & -0.39 & $0.70 * *$ & $0.60 * *$ & -0.55 & -0.62 & $0.99 *$ & $1.10^{* *}$ \\
\hline \& Fiscal Shocks & -0.47 & -0.45 & $0.74 * *$ & $0.72 * *$ & -0.87 & -0.96 & $0.96^{*}$ & $1.02 *$ \\
\hline \multicolumn{9}{|l|}{ US } \\
\hline This Study & 0.12 & 0.03 & 0.13 & 0.14 & 0.19 & 0.18 & 0.26 & 0.26 \\
\hline$\&$ Terms of Trade & 0.09 & 0.00 & 0.21 & 0.21 & 0.21 & 0.21 & 0.28 & 0.27 \\
\hline \& Real Exchg. Rate & 0.12 & 0.04 & 0.13 & 0.13 & 0.14 & 0.13 & 0.36 & 0.35 \\
\hline \& Fiscal Shocks & 0.14 & 0.02 & 0.14 & 0.13 & 0.26 & 0.24 & 0.27 & 0.27 \\
\hline
\end{tabular}

${ }^{1}$ Estimates based on re-scaled data for changes of current account and private investment.

* Statistically significant at the $10 \%$ level; ** statistically significant at the $5 \%$ level. 
Table 5: Parameter Estimates FIML - 1980-1998

Business Sector Data

Sensitivity to Country Composition ${ }^{1}$

\begin{tabular}{|c|c|c|c|c|c|c|c|c|}
\hline & \multicolumn{4}{|c|}{$\begin{array}{c}\text { G-7 Countries, Australia, Norway, } \\
\text { Sweden }\end{array}$} & \multicolumn{4}{|c|}{ "G-7 Countries ${ }^{2}$} \\
\hline & \multicolumn{2}{|c|}{ Country specific } & \multicolumn{2}{|c|}{ Global } & \multicolumn{2}{|c|}{ Country specific } & \multicolumn{2}{|c|}{ Global } \\
\hline & $\gamma_{2}$ & $\beta_{2}$ & $\gamma_{3}$ & $\beta_{3}$ & $\gamma_{2}$ & $\beta_{2}$ & $\gamma_{3}$ & $\beta_{3}$ \\
\hline Canada & -0.18 & 0.05 & -0.98 & 0.80 & -0.25 & 0.04 & -1.01 & 0.79 \\
\hline France & $-0.46 * *$ & $0.73 * *$ & 0.07 & $0.88^{*}$ & $-0.47 * *$ & $0.73 * *$ & 0.04 & $0.92 *$ \\
\hline Germany & $-0.55 * *$ & $0.56^{* *}$ & -0.17 & $0.69 * *$ & $-0.55 * *$ & $0.56 * *$ & -0.17 & $0.70 * *$ \\
\hline Italy & -0.20 & 0.08 & -0.29 & 0.21 & -0.20 & 0.06 & -0.28 & 0.24 \\
\hline Japan & $-0.34 * *$ & $1.04 * *$ & -0.17 & $1.18 * *$ & $-0.34 * *$ & $1.04 * *$ & -0.19 & $1.19 * *$ \\
\hline UK & -0.13 & -0.09 & -0.63 & $0.97 *$ & -0.06 & -0.09 & -0.62 & $0.98 *$ \\
\hline US & $-0.55 * *$ & $0.54 *$ & 0.14 & 0.33 & $-0.61 * *$ & $0.60 * *$ & 0.19 & 0.26 \\
\hline
\end{tabular}

${ }^{1}$ Estimates based on re-scaled data for changes of current account and private investment.

2 Estimates from tables 3 and 4, row "This Study."

* Statistically significant at the $10 \%$ level; ** statistically significant at the $5 \%$ level. 
Table 6: Parameter Estimates FIML - 1980-1998

Sensitivity to Measure of $R \& D^{1}$

Canada

\begin{tabular}{lcccc}
\hline \hline & $\mathrm{R}_{1}$ & $\mathrm{R}_{2}$ & $\mathrm{R}_{3}$ & $\mathrm{R}_{4}$ \\
$\gamma_{2}$ & 2.964 & 3.663 & 5.710 & 6.356 \\
& 5.239 & 7.539 & 15.120 & 18.300 \\
$\gamma_{3}$ & 0.057 & 0.584 & 1.840 & 2.358 \\
& 2.591 & 4.014 & 8.257 & 10.390 \\
$\beta_{2}$ & -6.212 & -7.613 & -10.595 & -11.643 \\
& 9.212 & 13.820 & 26.740 & 32.240 \\
$\beta_{3}$ & -1.577 & -2.687 & -4.592 & -5.465 \\
& 4.519 & 7.246 & 14.520 & 18.220 \\
& & & & \\
$\eta_{1}$ & -0.647 & 0.001 & 4.197 & 3.398 \\
& 2.417 & 0.011 & 6.730 & 4.610 \\
& & & & \\
$\eta_{2}$ & -0.511 & -0.434 & -0.425 & -0.407 \\
& 0.320 & 0.243 & 0.256 & 0.244 \\
& & & & \\
$\eta_{3}$ & 1.045 & 0.911 & 0.906 & 0.859 \\
& 0.565 & 0.412 & 0.465 & 0.449 \\
& & & & \\
$\eta_{4}$ & -0.005 & -0.027 & -0.045 & -0.056 \\
& 0.082 & 0.029 & 0.039 & 0.048 \\
\hline \hline
\end{tabular}

${ }^{1}$ Estimates based on re-scaled data for changes of current account and private investment. For each entry, the top figure is the point estimate and the bottom figure is the estimated standard error.

$\mathrm{R}_{1}$ : GDP share of R\&D expenditures.

$\mathrm{R}_{2}$ : GDP share of cumulated $R \& D$ expenditures.

$\mathrm{R}_{3}$ : Number of researchers per capita

$\mathrm{R}_{4}$ : Number of scientists and engineers in $\mathrm{R} \& \mathrm{D}$ sector per capita

$\gamma_{2}$ : effect of country-specific productivity shock on CA (equation 14)

$\gamma_{3}$ : effect of global productivity shock on CA (equation 14)

$\beta_{2}$ : effect of country-specific productivity shock on I (equation 15 )

$\beta_{3}$ : effect of global productivity shock on I (equation 15 )

$\eta_{1}$ : effect of $\mathrm{R}_{\mathrm{i}}$ on domestic productivity growth (equation 17 )

$\eta_{2}$ : effect of output gap on domestic productivity growth (equation 17 )

$\eta_{3}$ : effect of changes in investment on domestic productivity growth (equation 17)

$\eta_{4}$ : effect of investment (lagged) on domestic productivity growth (equation 17) 
Table 6: Parameter Estimates FIML - 1980-1998 (continued)

Sensitivity to Measure of $R \& D^{1}$

France

\begin{tabular}{|c|c|c|c|c|}
\hline & $\mathrm{R}_{1}$ & $\mathrm{R}_{2}$ & $\mathrm{R}_{3}$ & $\mathrm{R}_{4}$ \\
\hline \multirow[t]{2}{*}{$\gamma_{2}$} & -0.561 & -0.575 & -0.700 & -0.709 \\
\hline & 0.180 & 0.202 & 0.248 & 0.267 \\
\hline \multirow{2}{*}{$\gamma_{3}$} & 0.006 & -0.009 & -0.139 & -0.150 \\
\hline & 0.240 & 0.254 & 0.307 & 0.320 \\
\hline \multirow[t]{2}{*}{$\beta_{2}$} & 1.574 & 1.739 & 1.769 & 1.952 \\
\hline & 0.544 & 0.651 & 0.633 & 0.739 \\
\hline \multirow[t]{2}{*}{$\beta_{3}$} & 1.570 & 1.737 & 1.768 & 1.952 \\
\hline & 0.546 & 0.652 & 0.633 & 0.739 \\
\hline \multirow[t]{2}{*}{$\eta_{1}$} & -0.312 & 0.001 & -1.364 & -0.996 \\
\hline & 0.690 & 0.002 & 3.625 & 3.279 \\
\hline \multirow[t]{2}{*}{$\eta_{2}$} & 0.056 & 0.053 & 0.048 & 0.032 \\
\hline & 0.123 & 0.143 & 0.129 & 0.104 \\
\hline \multirow[t]{2}{*}{$\eta_{3}$} & 0.600 & 0.539 & 0.533 & 0.491 \\
\hline & 0.204 & 0.203 & 0.193 & 0.186 \\
\hline \multirow{2}{*}{$\eta_{4}$} & 0.079 & 0.062 & 0.065 & 0.072 \\
\hline & 0.054 & 0.022 & 0.029 & 0.056 \\
\hline
\end{tabular}

${ }^{1}$ Estimates based on re-scaled data for changes of current account and private investment. For each entry, the top figure is the point estimate and the bottom figure is the estimated standard error.

$\mathrm{R}_{1}$ : GDP share of $\mathrm{R} \& \mathrm{D}$ expenditures.

$\mathrm{R}_{2}$ : GDP share of cumulated $R \& D$ expenditures.

$\mathrm{R}_{3}$ : Number of researchers per capita

$\mathrm{R}_{4}$ : Number of scientists and engineers in $\mathrm{R} \& \mathrm{D}$ sector per capita

$\gamma_{2}$ : effect of country-specific productivity shock on CA (equation 14)

$\gamma_{3}$ : effect of global productivity shock on CA (equation 14)

$\beta_{2}$ : effect of country-specific productivity shock on I (equation 15 )

$\beta_{3}$ : effect of global productivity shock on I (equation 15)

$\eta_{1}$ : effect of $\mathrm{R}_{\mathrm{i}}$ on domestic productivity growth (equation 17)

$\eta_{2}$ : effect of output gap on domestic productivity growth (equation 17)

$\eta_{3}$ : effect of changes in investment on domestic productivity growth (equation 17)

$\eta_{4}$ : effect of investment (lagged) on domestic productivity growth (equation 17) 
Table 6: Parameter Estimates FIML - 1980-1998 (continued)

Sensitivity to Measure of $R \& D^{1}$

Germany

\begin{tabular}{ccc}
\hline \hline & $\mathrm{R}_{1}$ & $\mathrm{R}_{2}$ \\
$\gamma_{2}$ & -1.237 & -1.563 \\
& 0.792 & 1.843 \\
$\gamma_{3}$ & -0.967 & -1.291 \\
& 0.988 & 2.022 \\
$\beta_{2}$ & 1.913 & 2.391 \\
& 1.237 & 3.072 \\
$\beta_{3}$ & 2.255 & 2.664 \\
& 1.510 & 3.361 \\
$\eta_{1}$ & 4.998 & 0.003 \\
& 1.828 & 0.008 \\
$\eta_{2}$ & 0.832 & 0.623 \\
& 0.410 & 0.456 \\
$\eta_{3}$ & -1.915 & -1.700 \\
& 0.469 & 0.517 \\
$\eta_{4}$ & -0.286 & 0.088 \\
& 0.136 & 0.071 \\
\hline \hline
\end{tabular}

${ }^{1}$ Estimates based on re-scaled data for changes of current account and private investment. For each entry, the top figure is the point estimate and the bottom figure is the estimated standard error.

$\mathrm{R}_{1}$ : GDP share of $\mathrm{R} \& \mathrm{D}$ expenditures.

$\mathrm{R}_{2}$ : GDP share of cumulated $R \& D$ expenditures.

$\gamma_{2}$ : effect of country-specific productivity shock on CA (equation 14)

$\gamma_{3}$ : effect of global productivity shock on CA (equation 14)

$\beta_{2}$ : effect of country-specific productivity shock on I (equation 15 )

$\beta_{3}$ : effect of global productivity shock on I (equation 15)

$\eta_{1}$ : effect of $\mathrm{R}_{\mathrm{i}}$ on domestic productivity growth (equation 17 )

$\eta_{2}$ : effect of output gap on domestic productivity growth (equation 17)

$\eta_{3}$ : effect of changes in investment on domestic productivity growth (equation 17)

$\eta_{4}$ : effect of investment (lagged) on domestic productivity growth (equation 17) 
Table 6: Parameter Estimates FIML - 1980-1998 (continued)

Sensitivity to Measure of $R \& D^{1}$

Italy

\begin{tabular}{cccc}
\hline \hline & $\mathrm{R}_{1}$ & $\mathrm{R}_{2}$ & $\mathrm{R}_{4}$ \\
$\gamma_{2}$ & 6.641 & 6.628 & 8.333 \\
& 18.860 & 18.040 & 29.200 \\
$\gamma_{3}$ & 4.292 & 3.567 & 6.616 \\
& 12.830 & 10.600 & 23.460 \\
$\beta_{2}$ & -6.195 & -5.902 & -7.751 \\
& 16.900 & 15.450 & 26.320 \\
$\beta_{3}$ & -3.948 & -3.121 & -6.072 \\
& 11.490 & 9.078 & 21.150 \\
$\eta_{1}$ & 1.064 & 6.076 & 12.499 \\
& 1.253 & 22.510 & 9.679 \\
& & & \\
$\eta_{2}$ & -0.479 & -0.537 & -0.377 \\
& 0.222 & 0.252 & 0.203 \\
$\eta_{3}$ & 0.799 & 0.937 & 0.563 \\
& 0.447 & 0.542 & 0.427 \\
$\eta_{4}$ & -0.001 & 0.015 & -0.037 \\
& 0.040 & 0.056 & 0.058 \\
\hline \hline
\end{tabular}

${ }^{1}$ Estimates based on re-scaled data for changes of current account and private investment. For each entry, the top figure is the point estimate and the bottom figure is the estimated standard error.

$\mathrm{R}_{1}$ : GDP share of $\mathrm{R} \& \mathrm{D}$ expenditures.

$\mathrm{R}_{2}$ : GDP share of cumulated $R \& D$ expenditures.

$\mathrm{R}_{4}$ : Number of scientists and engineers in $R \& D$ sector per capita

$\gamma_{2}$ : effect of country-specific productivity shock on CA (equation 14)

$\gamma_{3}$ : effect of global productivity shock on CA (equation 14)

$\beta_{2}$ : effect of country-specific productivity shock on I (equation 15 )

$\beta_{3}$ : effect of global productivity shock on I (equation 15 )

$\eta_{1}$ : effect of $\mathrm{R}_{\mathrm{i}}$ on domestic productivity growth (equation 17 )

$\eta_{2}$ : effect of output gap on domestic productivity growth (equation 17)

$\eta_{3}$ : effect of changes in investment on domestic productivity growth (equation 17)

$\eta_{4}$ : effect of investment (lagged) on domestic productivity growth (equation 17) 
Table 6: Parameter Estimates FIML - 1980-1998 (continued)

Sensitivity to Measure of $R \& D^{1}$

Japan

\begin{tabular}{lcccc}
\hline \hline & $\mathrm{R}_{1}$ & $\mathrm{R}_{2}$ & $\mathrm{R}_{3}$ & $\mathrm{R}_{4}$ \\
$\gamma_{2}$ & -0.201 & -0.295 & -0.374 & -0.324 \\
& 0.234 & 0.195 & 0.182 & 0.211 \\
$\gamma_{3}$ & -0.072 & -0.065 & -0.155 & -0.156 \\
& 0.325 & 0.260 & 0.252 & 0.289 \\
$\beta_{2}$ & 1.263 & 1.197 & 1.242 & 1.299 \\
& 0.214 & 0.181 & 0.171 & 0.200 \\
$\beta_{3}$ & 1.402 & 1.199 & 1.277 & 1.329 \\
& 0.296 & 0.183 & 0.188 & 0.237 \\
& & & & \\
$\eta_{1}$ & 3.124 & -0.003 & -9.783 & 13.145 \\
& 3.400 & 0.003 & 8.367 & 10.290 \\
& & & & \\
$\eta_{2}$ & 0.298 & -0.079 & -0.189 & 0.265 \\
& 0.392 & 0.073 & 0.160 & 0.241 \\
& & & & \\
$\eta_{3}$ & 0.137 & 0.899 & 0.965 & 0.434 \\
& 0.806 & 0.128 & 0.157 & 0.333 \\
& & & & \\
$\eta_{4}$ & -0.453 & 0.127 & 0.384 & -0.561 \\
& 0.585 & 0.044 & 0.256 & 0.507 \\
\hline \hline
\end{tabular}

${ }^{1}$ Estimates based on re-scaled data for changes of current account and private investment. For each entry, the top figure is the point estimate and the bottom figure is the estimated standard error.

$\mathrm{R}_{1}$ : GDP share of $\mathrm{R} \& \mathrm{D}$ expenditures.

$\mathrm{R}_{2}$ : GDP share of cumulated $R \& D$ expenditures.

$\mathrm{R}_{3}$ : Number of researchers per capita

$\mathrm{R}_{4}$ : Number of scientists and engineers in $R \& D$ sector per capita

$\gamma_{2}$ : effect of country-specific productivity shock on CA (equation 14)

$\gamma_{3}$ : effect of global productivity shock on CA (equation 14)

$\beta_{2}$ : effect of country-specific productivity shock on I (equation 15)

$\beta_{3}$ : effect of global productivity shock on I (equation 15 )

$\eta_{1}$ : effect of $\mathrm{R}_{\mathrm{i}}$ on domestic productivity growth (equation 17 )

$\eta_{2}$ : effect of output gap on domestic productivity growth (equation 17)

$\eta_{3}$ : effect of changes in investment on domestic productivity growth (equation 17)

$\eta_{4}$ : effect of investment (lagged) on domestic productivity growth (equation 17) 


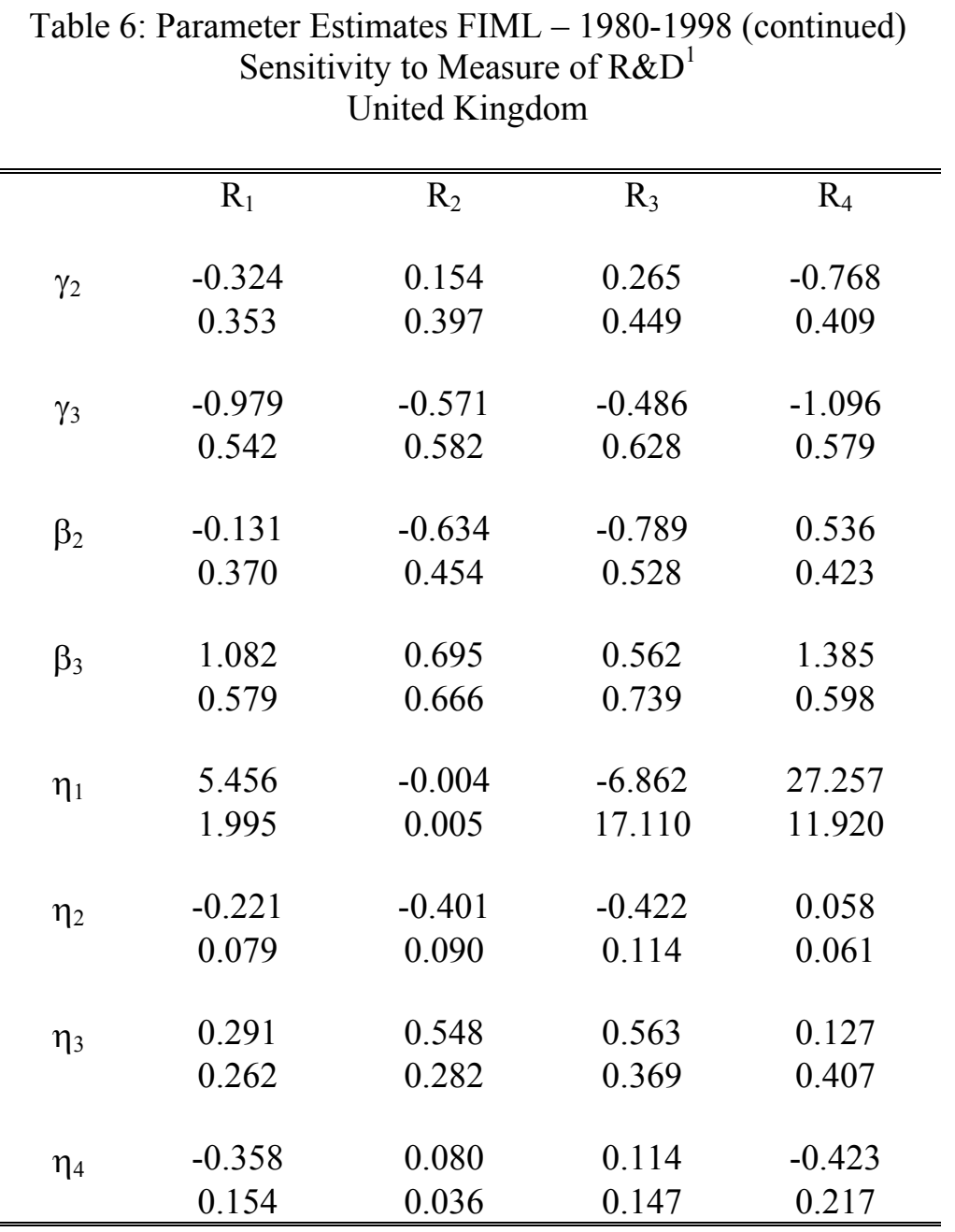

${ }^{1}$ Estimates based on re-scaled data for changes of current account and private investment. For each entry, the top figure is the point estimate and the bottom figure is the estimated standard error.

$\mathrm{R}_{1}$ : GDP share of $\mathrm{R} \& \mathrm{D}$ expenditures.

$\mathrm{R}_{2}$ : GDP share of cumulated $R \& D$ expenditures.

$\mathrm{R}_{3}$ : Number of researchers per capita

$\mathrm{R}_{4}$ : Number of scientists and engineers in $\mathrm{R} \& \mathrm{D}$ sector per capita

$\gamma_{2}$ : effect of country-specific productivity shock on CA (equation 14)

$\gamma_{3}$ : effect of global productivity shock on CA (equation 14)

$\beta_{2}$ : effect of country-specific productivity shock on I (equation 15)

$\beta_{3}$ : effect of global productivity shock on I (equation 15)

$\eta_{1}$ : effect of $\mathrm{R}_{\mathrm{i}}$ on domestic productivity growth (equation 17 )

$\eta_{2}$ : effect of output gap on domestic productivity growth (equation 17)

$\eta_{3}$ : effect of changes in investment on domestic productivity growth (equation 17)

$\eta_{4}$ : effect of investment (lagged) on domestic productivity growth (equation 17) 
Table 6: Parameter Estimates FIML - 1980-1998 (continued)

Sensitivity to Measure of $R \& D^{1}$

United States

\begin{tabular}{lccc}
\hline \hline & $\mathrm{R}_{1}$ & $\mathrm{R}_{2}$ & $\mathrm{R}_{3}$ \\
$\gamma_{2}$ & -2.049 & -1.840 & -1.540 \\
& 1.125 & 0.931 & 0.690 \\
$\gamma_{3}$ & 0.812 & 0.792 & 0.592 \\
& 0.711 & 0.605 & 0.484 \\
$\beta_{2}$ & -0.337 & -0.187 & -0.113 \\
& 0.740 & 0.651 & 0.597 \\
$\beta_{3}$ & 1.145 & 1.023 & 1.038 \\
& 0.468 & 0.408 & 0.413 \\
& & & \\
$\eta_{1}$ & 1.966 & -9.879 & 2.798 \\
& 1.543 & 10.730 & 4.043 \\
& & & \\
$\eta_{2}$ & -0.210 & -0.290 & -0.242 \\
& 0.164 & 0.279 & 0.235 \\
$\eta_{3}$ & 1.644 & 1.886 & 1.780 \\
& 0.509 & 0.680 & 0.592 \\
$\eta_{4}$ & -0.232 & 0.235 & -0.058 \\
& 0.199 & 0.240 & 0.097 \\
\hline \hline
\end{tabular}

${ }^{1}$ Estimates based on re-scaled data for changes of current account and private investment. For each entry, the top figure is the point estimate and the bottom figure is the estimated standard error.

$\mathrm{R}_{1}$ : GDP share of $\mathrm{R} \& \mathrm{D}$ expenditures.

$\mathrm{R}_{2}$ : GDP share of cumulated $R \& D$ expenditures.

$\mathrm{R}_{3}$ : Number of researchers per capita

$\gamma_{2}$ : effect of country-specific productivity shock on CA (equation 14)

$\gamma_{3}$ : effect of global productivity shock on CA (equation 14)

$\beta_{2}$ : effect of country-specific productivity shock on I (equation 15 )

$\beta_{3}$ : effect of global productivity shock on I (equation 15 )

$\eta_{1}$ : effect of $\mathrm{R}_{\mathrm{i}}$ on domestic productivity growth (equation 17 )

$\eta_{2}$ : effect of output gap on domestic productivity growth (equation 17)

$\eta_{3}$ : effect of changes in investment on domestic productivity growth (equation 17)

$\eta_{4}$ : effect of investment (lagged) on domestic productivity growth (equation 17) 